\title{
A study of chewing during eating in the cow
}

\author{
By J. GILL,* R. C. CAMPLING† AND D. R. WESTGARTH \\ National Institute for Research in Dairying, Shinfield, Reading
}

(Received 12 March 1965-Accepted 14 September 1965)

\begin{abstract}
r. A preliminary study was made of chewing during eating with a total of sixcows with rumen fistulas, given diets of hay or herbage. A sieving technique was used to determine the size of particles of food swallowed at intervals throughout the eating period. The number of jaw movements, number and weight of the swallowed food boluses and the time spent eating were measured with each diet. 2 . The mean particle size of hay contained in a bolus collected at the cardia varied between individual cows from $1602 \mu \mathrm{m}$ to $1244 \mu \mathrm{m}$. Boluses swallowed in the first few minutes of eating contained particles of a larger average size than those at any other time during the meal. Also, the rate of swallowing boluses of food was much faster at the beginning of a meal and the weight of boluses smaller than at any other time. The frequency of jaw movements did not vary appreciably during a meal. 3. Increasing the amount of hay given to the cows by $50 \%$ or giving a different hay did not cause any significant alteration in the average size of particles of swallowed hay, and changes in the rate of swallowing boluses, or in, the rate of jaw movements and the size of boluses were not very marked. 4. With a diet of herbage, boluses were swallowed rapidly and the average particle size of swallowed food was larger than that of hay. Also, there were slightly more jaw movements per min and larger boluses than with hay. 5. The observations made in the study are discussed in relation to possible factors that determine the particle size of swallowed food.
\end{abstract}

When food is chewed during eating it is mixed with saliva and broken into small particles which, especially with the dry bulky foods eaten by ruminants, ensures that it can be swallowed readily (Dukes, 1955). Reduction in the size of particles of food during eating and ruminating is also important in increasing the surfaces of the food available for microbial digestion and in producing particles small enough to pass through the reticulo-omasal orifice. The rate of production of small particles of food is an important factor affecting the rate of passage of food through the alimentary tract and this in turn affects the amount of hay a cow can eat (Campling, Freer \& Balch, I961; Balch \& Campling, I962). Although in the cow the secretion of saliva during eating has been studied intensively (Schalk \& Amadon, 1928; Balch, 1958; Bailey \& Balch, 196r; Bailey, I961), little is known of the effect of chewing during eating in reducing the size of particles of food. The only report known to us is that of Silver (r935), who, by sieving, examined the effects of eating and of ruminating on the particle size of swallowed food and of digesta in four steers given hay in various physical forms. Recently, Reid, Lyttleton \& Mangan (1962) devised a chemical method of measuring the effectiveness of chewing during eating by determining the release of plant cell contents from herbage, and these workers and Bryant (1964) have used the method in investigations of bloat in cattle. Unfortunately the results of the study by Silver (1935) were reported only briefly, the composition and amount of the hay eaten by the steers was not given, nor were any details of eating behaviour and the time spent eating

* Present address: Katedra Fizjologii Zwierzat, Wydz. Wet., Warszawa 26, Grochowska 272, Poland.

$\dagger$ Present address: Wye College, Nr Ashford, Kent. 
reported. Information on the time spent eating and the number of jaw movements during eating in steers given lucerne hay in various physical forms and mixed diets of hay, maize and a protein supplement were reported, however, by Silver and his colleagues in a related study (Kick \& Gerlaugh, 1935; Kick, Gerlaugh, Schalk \& Silver, 1937). Several other workers have observed the times spent eating and ruminating by cows given a variety of diets (e.g. Schalk \& Amadon, 1928; Freer, Campling $\&$ Balch, I962), the number of jaw movements during eating (Fuller, I928; Hancock, I950; Balch, 1958; Duckworth \& Shirlaw, I958) and the size, shape and dry-matter content of the bolus (Schalk \& Amadon, I928), but information on all these factors has not been collected simultaneously with measurements of the size of swallowed food particles. Troelsen \& Bigsby (I964) recently published results showing a close direct relationship between the voluntary intake of different roughages by sheep and the size of particles of roughage produced by a technique of artificial mastication.

The present report is of a preliminary study to examine (I) the variation between individual cows in the size of particles of swallowed food and (2) the effect of different diets on the size of particles of food produced during eating. At the same time information was also collected on the time spent eating, the number of jaw movements and the number and weight of the boluses of swallowed food.

\section{EXPERIMENTAL}

Expt 1. Each of six cows (Dorrit 36, Begum, Polly 2, Elite, Polly and Sylph) were given daily $5 \mathrm{~kg}$ hay A during a preliminary period of Io days, and then on each of 3 days boluses of swallowed food were collected by hand in duplicate from the cardia of each of the cows on four occasions during a meal: at the beginning, the end and at two equally spaced intervals during the meal. The days for the different cows did not coincide. Most of the cows spent about 70 min eating $5 \mathrm{~kg}$ hay; boluses were collected about every $23 \mathrm{~min}$ throughout a meal. The swallowed food was examined and measurements made of the size of particles of hay in each bolus. In another period of 3 days, while the cows received the same diet, boluses were collected in exactly the same way and the total weight and dry-matter content of each bolus was determined. On a further 3 days the numbers of jaw movements per bolus swallowed were recorded together with the time spent eating by each cow. The results were analysed to see the extent of the variation in the efficiency of chewing between individual cows.

Expt i $a$. In this part of the experiment the effect of the amount and type of hay on the particle size of swallowed food was studied in three cows (Dorrit 36 , Begum and Polly). Each cow received in turn the following daily diets: (I) $7.5 \mathrm{~kg}$ hay A, (2) $5.0 \mathrm{~kg}$ hay B, and the results were compared with those found in Expt I.

Expt $\mathrm{I} b$. The effect of chewing on the particle size of freshly cut herbage was examined in two cows (Sylph and Polly) given $4.3 \mathrm{~kg}$ herbage dry matter daily. The results were compared with those found in Expt I. The preliminary feeding period, the collection of boluses and recording of jaw movements and swallowing in Expt $\mathrm{r} a$ were as in Expt $\mathbf{I}$. In Expt $\mathbf{I} b$ the changing composition of the growing herbage made it essential to complete the experiments as quickly as possible. The cows used in 
Expt $\mathrm{I} b$ (Sylph and Polly) were put out to graze for a period of 3 weeks and then brought indoors and given freshly cut herbage for a period of $\mathrm{I} 3$ days. During the last 6 days of this period the collection of boluses and recordings of jaw movements were made separately on alternate days. The boluses for analysis of particle size were stored immediately after collection at $-15^{\circ}$.

Cows and management. Six adult non-lactating cows were used, five of which were Friesian and one (Dorrit 36) Shorthorn. The average weight of these animals was $525 \mathrm{~kg}$. One of the cows (Polly 2) was between 3 and 6 months pregnant during the study; the other five cows were not pregnant. Each cow had a permanent rumen fistula closed by a rubber cannula and bung (Balch \& Cowie, I962). The cows were kept in individual standings in a metabolism house (Balch, Johnson \& Machin, 1962). Water and salt licks containing trace minerals were always available. Food was given to the cows in one meal daily at $10.00 \mathrm{~h}$.

Foods. There were two separate batches of hay (A and B); hay A used in Expt I was predominantly mature Timothy (Phleum pratense L.) cut 25 June 1962 and conserved during fine weather. The average length of the particles of this hay was $35 \mathrm{~cm}$. Hay B, used in Expt $\mathrm{I} a$, was mainly mature Italian ryegrass (Lolium multiflorum) with a small amount of red clover (Trifolium pratense L.) and was cut in late June 1963 . The length of most of the particles of hay B was about $38 \mathrm{~cm}$ but it included about $12 \%$ by weight of loose grass seeds and broken clover leaves. Hay B was dusty and had been conserved during showery weather. The fresh herbage used in Expt $\mathrm{I} b$ was cut daily by a reciprocating mower from a pasture of predominantly Italian ryegrass with a little red and white clover. The cut herbage was about $30 \mathrm{~cm}$ long. The mean date of cutting was 9 July 1964 and it was the second growth of grass of the season; the first growth was cut on 27 May. The chemical composition of the hays and herbage are given in Table $\mathrm{I}$.

Table I. Chemical composition of the foods

\begin{tabular}{|c|c|c|c|c|c|c|c|}
\hline \multirow{2}{*}{$\begin{array}{c}\text { Expt } \\
\text { no. }\end{array}$} & & \multirow{2}{*}{$\begin{array}{c}\text { Dry } \\
\text { matter } \\
(\%)\end{array}$} & $\begin{array}{l}\text { Crude } \\
\text { protein }\end{array}$ & $\begin{array}{l}\text { Ether } \\
\text { extract }\end{array}$ & $\begin{array}{l}\text { Crude } \\
\text { fibre }\end{array}$ & $\begin{array}{c}\text { Nitrogen- } \\
\text { free } \\
\text { extract }\end{array}$ & Ash \\
\hline & Food & & \multicolumn{5}{|c|}{ (as $\%$ dry matter) } \\
\hline $\begin{array}{l}\text { I } \\
\text { I } a\end{array}$ & $\begin{array}{l}\text { Hay A } \\
\text { Hay B }\end{array}$ & $\begin{array}{l}83 \cdot 1 \\
82 \cdot 7\end{array}$ & $\begin{array}{l}8 \cdot 4 \\
9 \cdot 2\end{array}$ & $\begin{array}{l}\mathrm{I} .4 \\
0.8\end{array}$ & $\begin{array}{l}34 \cdot 3 \\
36 \cdot 0\end{array}$ & $\begin{array}{l}50 \cdot \mathrm{I} \\
45^{\circ} \cdot 8\end{array}$ & $\begin{array}{l}5 \cdot 8 \\
8 \cdot 2\end{array}$ \\
\hline I $b$ & Herbage & $2 I \cdot x$ & 10.2 & $\mathrm{r}-8$ & $25 \cdot 0$ & $55 \cdot 3$ & $7 \cdot 7$ \\
\hline
\end{tabular}

Measurement of size of particles of swallowed food. The counting and measuring of many individual particles of swallowed food is extremely laborious, and we have used an empirical method of sieving a sample of swallowed food through a series of sieves and estimating the size of mesh through which half the total weight of swallowed food would pass. The boluses were prepared for sieving by drying the material after the following treatment to remove saliva and to prevent clumping of the particles during drying. The bolus was placed in a bag made of finely woven nylon cloth and washed thoroughly in hot water for about $2 \mathrm{~min}$. The bag and its contents were then transferred to a large beaker containing a solution of about $0.01 \mathrm{~N}$-sodium hydroxide and 
soaked in the solution for 4-5 min. This was repeated four times with fresh solutions of sodium hydroxide. Lastly the bag and contents were immersed for $5 \mathrm{~min}$ in $95 \%$ ethyl alcohol, removed and allowed to drain; the bolus was then emptied from the nylon bag and dried carefully. The air-dried material was sieved through a series of test sieves (British Standard Specification 410, 1943) on a mechanical sieve shaker for ro min. The size of the apertures of each sieve is given in Table 2. The amount of material remaining on each sieve was weighed and the cumulative percentage weight of particles was plotted on semi-log graph paper against the size of the apertures of the sieves. The average particle size was defined by the median of the weight distribution, i.e. the size of mesh through which half the total weight of particles would pass. This median is larger than the frequency distribution median, which is the particle size exceeded by half the total number of particles, but the precise relationship is unknown.

Table 2. Size of the aperture of the sieves

$\begin{array}{cccc}\text { Mesh no. } & \text { Aperture }(\mu \mathrm{m}) & \text { Mesh no. } & \text { Aperture }(\mu \mathrm{m}) \\ \frac{3}{8} \text { in. } & 953^{\circ} & 25 & 599 \\ \frac{3}{16} \text { in. } & 4760 & 52 & 295 \\ 7 & 2411 & 100 & 152 \\ 14 & 1204 & & \end{array}$

Measurement of jaw movements. The technique used for recording the jaw movements was similar to that described by Balch (1958). A small lightly inflated balloon mounted on a perforated brass tube was tied under a side strap of a leather head-stall worn by the cow. The balloon was connected with rubber tubing to a tambour operating a pen in a recorder running with a chart speed of $4 \mathrm{in} / \mathrm{min}$. The number of jaw movements per min was determined and also the number of movements required for each bolus of food swallowed during four periods, each of $5 \mathrm{~min}$, at the beginning, the end and at two approximately equal intervals during a meal. The time of swallowing a bolus of food was seen on the recorder chart as a very short pause between continuous jaw movements, and to confirm the time of swallowing of a bolus the passage through the cardia of each bolus was felt by hand and recorded on the chart.

Weight of wet and dry boluses. Boluses were caught by hand at the cardia in duplicate on four occasions during a meal; each bolus was weighed immediately and dried at $100^{\circ}$ to determine the content of dry matter.

\section{RESULTS}

\section{Size of particles of swallowed food}

Expt I. On average, the median size of particles of swallowed hay produced when the cows ate $5 \mathrm{~kg}$ hay A was ${ }^{3} 367 \mu \mathrm{m}$, but there were highly significant differences between cows in the median size $(P<0.001)$. The largest size was found in Dorrit $3^{6}$ $(1600 \mu \mathrm{m})$, and the median size of particles in the other five cows varied only slightly from $1406 \mu \mathrm{m}$ in Begum to $1244 \mu \mathrm{m}$ in Polly 2 (Table 3 ). The analysis of the size of particles contained in successive boluses collected throughout a meal showed 
that there was a significant decline in the median size of particles from the beginning to the end of a meal (Table 4), the reduction being particularly marked during the first third of a meal.

Expt I $a$. The mean values given in Table 5 show only small and statistically nonsignificant differences between the mean median particle size of swallowed food from the two diets in Expt I $a$ and that used in Expt I. Differences between individual cows in the mean median size of particles of food were similar with each of the three diets; in Dorrit 36 the particle size was largest and in Polly 2 smallest. It was observed with both $7 \cdot 5 \mathrm{~kg}$ hay A and $5 \mathrm{~kg}$ hay B that the mean particle size of food became smaller as the meal progressed (Table 6), a result which was similar to that found with $5 \mathrm{~kg}$ hay $\mathrm{A}$ in Expt $\mathrm{I}$.

Expt $\mathrm{I} b$. The mean median size of particles of swallowed herbage was $2070 \mu \mathrm{m}$, which was significantly greater $(P<0.00 \mathrm{I})$ than the value of $13 \mathrm{I} 4 \mu \mathrm{m}$ found with $5 \mathrm{~kg}$ hay A (Table 7); this difference was seen in both Sylph and Polly. At each time

Table 3. Expt 1. Mean particle size of swallowed hay, time spent eating, numbers of jaw movements and of food boluses and weight of a bolus, determined on 3 days in each of six cows receiving daily $5 \mathrm{~kg}$ hay $A$

\begin{tabular}{|c|c|c|c|c|c|c|c|}
\hline \multirow[b]{2}{*}{ Cow } & \multirow{2}{*}{$\begin{array}{c}\text { Median } \\
\text { particle } \\
\text { size of } \\
\text { swallowed } \\
\text { hay } \\
(\mu \mathrm{m})\end{array}$} & \multirow{2}{*}{$\begin{array}{l}\text { Time } \\
\text { spent } \\
\text { eating } \\
\text { (min) }\end{array}$} & \multicolumn{2}{|c|}{$\begin{array}{r}\begin{array}{c}\text { No. of } \\
\text { jaw } \\
\text { movements }\end{array} \\
.\end{array}$} & \multirow{2}{*}{$\begin{array}{l}\text { No. of } \\
\text { boluses/ } \\
\text { min }\end{array}$} & \multicolumn{2}{|c|}{$\begin{array}{l}\text { Weight of } \\
\text { bolus }(\mathrm{g})\end{array}$} \\
\hline & & & $\begin{array}{l}\text { Per } \\
\text { min }\end{array}$ & $\begin{array}{c}\text { Per } \\
\text { bolus }\end{array}$ & & $\widetilde{\text { Wet }}$ & Dry \\
\hline Dorrit 36 & I 602 & 94 & 75 & $3 x$ & $2 \cdot 6$ & 173 & 27 \\
\hline Begum & 1406 & 78 & 74 & 23 & 3.4 & 132 & 20 \\
\hline Polly 2 & 1244 & 59 & 73 & 27 & $2 \cdot 8$ & 153 & 24 \\
\hline Elite & 1323 & 62 & 77 & 27 & $3 \cdot 0$ & 145 & 23 \\
\hline Sylph & 1348 & 62 & 72 & 26 & $2 \cdot 9$ & I 4 & 20 \\
\hline Polly & 1279 & 64 & 73 & 27 & $2 \cdot 8$ & 127 & $2 I$ \\
\hline $\begin{array}{l}\text { Mean } \\
\text { SE of difference } \\
\text { between two cov }\end{array}$ & $\begin{array}{r}1367 \\
\pm 553\end{array}$ & $\begin{array}{c}70 \\
\pm 5.3\end{array}$ & $\begin{array}{c}74 \\
\pm 2.5\end{array}$ & $\begin{array}{c}27 \\
\pm x \cdot 5\end{array}$ & $\begin{array}{c}2 \cdot 9 \\
\pm 0.12\end{array}$ & $\begin{array}{c}141 \\
\pm 10.8\end{array}$ & $\begin{array}{c}22 \\
\pm 1 \cdot 7\end{array}$ \\
\hline
\end{tabular}

Table 4. Expt I. Mean particle size of swallowed hay, numbers of jaw movements and of food boluses and weight of a bolus, determined on 3 days at intervals during a meal in six cows receiving daily $5 \mathrm{~kg}$ hay $A$

\begin{tabular}{|c|c|c|c|c|c|c|}
\hline \multirow[b]{3}{*}{ Time during meal } & \multirow{3}{*}{$\begin{array}{c}\text { Median } \\
\text { particle } \\
\text { size of } \\
\text { swallowed } \\
\text { hay } \\
(\mu \mathrm{m})\end{array}$} & \multicolumn{2}{|c|}{$\begin{array}{c}\text { No. of } \\
\text { jaw movements }\end{array}$} & \multirow{3}{*}{$\begin{array}{l}\text { No. of } \\
\text { boluses/ } \\
\text { min }\end{array}$} & \multirow{2}{*}{\multicolumn{2}{|c|}{ Weight of bolus (g) }} \\
\hline & & \multirow{2}{*}{$\begin{array}{l}\text { Per } \\
\text { min }\end{array}$} & \multirow{2}{*}{$\begin{array}{c}\text { Per } \\
\text { bolus }\end{array}$} & & & \\
\hline & & & & & Wet & Dry \\
\hline Beginning & I 486 & 73 & 18 & 4.0 & 88 & 12 \\
\hline One-third & 1376 & 77 & 27 & $2 \cdot 9$ & 162 & 26 \\
\hline Two-thirds & I316 & 72 & 29 & $2 \cdot 5$ & 167 & 28 \\
\hline End & 1291 & 74 & 33 & $2 \cdot 2$ & 146 & 24 \\
\hline $\begin{array}{l}\text { SE of difference between } \\
\text { two means* }\end{array}$ & $\pm 42 \cdot 1$ & $\pm 2 \cdot 1$ & $\pm x \cdot 4$ & \pm 0.14 & $\pm 7 \cdot 6$ & $\pm I \cdot 2$ \\
\hline
\end{tabular}

* Derived from 'cows $\times$ times', I 5 df. 
Table 5. Expt $\mathrm{I}$ a. Mean particle size of swallowed hay, time spent eating, numbers of jaw movements and of food boluses and weight of a bolus, determined on 3 days in three cows receiving each of three diets

\begin{tabular}{|c|c|c|c|c|c|c|c|c|}
\hline \multirow[b]{2}{*}{$\begin{array}{l}\text { Daily } \\
\text { diet }\end{array}$} & \multirow[b]{2}{*}{ Cow } & \multirow{2}{*}{$\begin{array}{c}\text { Median particle } \\
\text { size of } \\
\text { swallowed } \\
\text { hay } \\
(\mu \mathrm{m})\end{array}$} & \multirow{2}{*}{$\begin{array}{l}\text { Time } \\
\text { spent } \\
\text { eating } \\
\text { (min) }\end{array}$} & \multicolumn{2}{|c|}{$\begin{array}{l}\text { No. of jaw } \\
\text { movements }\end{array}$} & \multirow{2}{*}{$\begin{array}{c}\text { No. of } \\
\text { boluses/ } \\
\text { min }\end{array}$} & \multicolumn{2}{|c|}{$\begin{array}{l}\text { Weight of } \\
\text { bolus }(\mathrm{g})\end{array}$} \\
\hline & & & & $\begin{array}{l}\text { Per } \\
\text { min }\end{array}$ & $\begin{array}{l}\text { Per } \\
\text { bolus }\end{array}$ & & Wet & Dry \\
\hline $5 \mathrm{~kg}$ hay $\mathrm{A}^{*}$ & $\begin{array}{l}\text { Dorrit } 3^{6} \\
\text { Begum } \\
\text { Polly 2 } \\
\text { Mean }\end{array}$ & $\begin{array}{l}1602 \\
1406 \\
1244 \\
1417\end{array}$ & $\begin{array}{l}94 \\
78 \\
59 \\
77\end{array}$ & $\begin{array}{l}75 \\
74 \\
73 \\
74\end{array}$ & $\begin{array}{l}31 \\
23 \\
27 \\
27\end{array}$ & $\begin{array}{l}2 \cdot 6 \\
3 \cdot 4 \\
2 \cdot 8 \\
2 \cdot 9\end{array}$ & $\begin{array}{l}173 \\
\text { r } 32 \\
r 53 \\
\text { I } 53\end{array}$ & $\begin{array}{l}27 \\
20 \\
24 \\
24\end{array}$ \\
\hline $7.5 \mathrm{~kg}$ hay $\mathrm{A}$ & $\begin{array}{l}\text { Dorrit } 36 \\
\text { Begum } \\
\text { Polly } 2 \\
\text { Mean }\end{array}$ & $\begin{array}{l}1503 \\
1321 \\
1296 \\
1374\end{array}$ & $\begin{array}{l}152 \\
138 \\
122 \\
\text { I } 37\end{array}$ & $\begin{array}{l}73 \\
76 \\
75 \\
75\end{array}$ & $\begin{array}{l}35 \\
29 \\
34 \\
33\end{array}$ & $\begin{array}{l}2 \cdot 2 \\
3 \cdot 1 \\
2 \cdot 5 \\
2 \cdot 6\end{array}$ & $\begin{array}{l}161 \\
1 \times 9 \\
153 \\
144\end{array}$ & $\begin{array}{l}24 \\
18 \\
22 \\
21\end{array}$ \\
\hline $5 \mathrm{~kg}$ hay $\mathrm{B}$ & $\begin{array}{l}\text { Dorrit } 36 \\
\text { Begum } \\
\text { Polly } 2 \\
\text { Mean }\end{array}$ & $\begin{array}{l}1485 \\
1408 \\
1344 \\
1412\end{array}$ & $\begin{array}{l}89 \\
76 \\
67 \\
77\end{array}$ & $\begin{array}{l}80 \\
80 \\
78 \\
79\end{array}$ & $\begin{array}{l}36 \\
25 \\
32 \\
31\end{array}$ & $\begin{array}{l}2 \cdot 4 \\
3 \cdot 4 \\
2 \cdot 6 \\
2 \cdot 8\end{array}$ & $\begin{array}{l}\text { I7 I } \\
\text { I34 } \\
\text { I68 } \\
\text { I58 }\end{array}$ & $\begin{array}{l}25 \\
20 \\
26 \\
24\end{array}$ \\
\hline $\begin{array}{l}E \text { of a differer } \\
\text { two hay mea }\end{array}$ & between & $\pm 37 \cdot 4$ & $\pm 5 \cdot 2$ & $\pm I \cdot 0$ & $\pm I \cdot 0$ & \pm 0.07 & $\pm 5 \cdot 9$ & $\pm 1 \cdot 0$ \\
\hline
\end{tabular}

* Values from Expt i for comparison.

+ Derived from a pooled error of 'cows $\times$ hays', $4 \mathrm{df}$, and 'days within cows and hays', $18 \mathrm{df}$.

Table 6. Expt 1 a. Mean particle size of swallowed hay, numbers of jaw movements and of food boluses and weight of a bolus, determined on 3 days at intervals during a meal in three cows receiving each of three diets

\begin{tabular}{|c|c|c|c|c|c|c|c|}
\hline \multirow{2}{*}{$\begin{array}{l}\text { Time } \\
\text { during } \\
\text { meal }\end{array}$} & \multirow[b]{2}{*}{ Daily diet } & \multirow{2}{*}{$\begin{array}{c}\text { Median particle } \\
\text { size of } \\
\text { swallowed } \\
\text { hay } \\
(\mu \mathrm{m})\end{array}$} & \multicolumn{2}{|c|}{$\begin{array}{l}\text { No. of jaw } \\
\text { movements }\end{array}$} & \multirow{2}{*}{$\begin{array}{l}\text { No. of } \\
\text { boluses/ } \\
\text { min }\end{array}$} & \multicolumn{2}{|c|}{$\begin{array}{l}\text { Weight of } \\
\text { bolus }(g)\end{array}$} \\
\hline & & & $\begin{array}{l}\text { Per } \\
\text { min }\end{array}$ & $\begin{array}{c}\text { Per } \\
\text { bolus }\end{array}$ & & Wet & Dry \\
\hline Beginning & $\begin{array}{l}5.0 \mathrm{~kg} \text { hay } \mathrm{A}^{*} \\
7.5 \mathrm{~kg} \text { hay } \mathrm{A} \\
5.0 \mathrm{~kg} \text { hay } \mathrm{B}\end{array}$ & $\begin{array}{l}1564 \\
1631 \\
1518\end{array}$ & $\begin{array}{l}75 \\
72 \\
77\end{array}$ & $\begin{array}{l}18 \\
17 \\
20\end{array}$ & $\begin{array}{l}4 \cdot 0 \\
4 \cdot 2 \\
3 \cdot 8\end{array}$ & $\begin{array}{r}100 \\
99 \\
109\end{array}$ & $\begin{array}{l}13 \\
12 \\
14\end{array}$ \\
\hline One-third & $\begin{array}{l}5.0 \mathrm{~kg} \text { hay } A^{*} \\
7.5 \mathrm{~kg} \text { hay } \mathrm{A} \\
5.0 \mathrm{~kg} \text { hay } \mathrm{B}\end{array}$ & $\begin{array}{l}\text { I427 } \\
\text { I36I } \\
\text { I397 }\end{array}$ & $\begin{array}{l}77 \\
78 \\
82\end{array}$ & $\begin{array}{l}27 \\
3 x \\
28\end{array}$ & $\begin{array}{l}2 \cdot 9 \\
2 \cdot 5 \\
3 \cdot 0\end{array}$ & $\begin{array}{l}176 \\
173 \\
177\end{array}$ & $\begin{array}{l}28 \\
27 \\
26\end{array}$ \\
\hline Two-thirds & $\begin{array}{l}5.0 \mathrm{~kg} \text { hay } \mathrm{A} * \\
7.5 \mathrm{~kg} \text { hay } \mathrm{A} \\
5.0 \mathrm{~kg} \text { hay B }\end{array}$ & $\begin{array}{l}1360 \\
1277 \\
1383\end{array}$ & $\begin{array}{l}74 \\
76 \\
8 \mathrm{I}\end{array}$ & $\begin{array}{l}29 \\
39 \\
36\end{array}$ & $\begin{array}{l}2 \cdot 7 \\
2 \cdot 0 \\
2 \cdot 3\end{array}$ & $\begin{array}{l}\mathbf{1} 77 \\
\mathbf{I} 63 \\
\text { I } 9 \text { I }\end{array}$ & $\begin{array}{l}29 \\
25 \\
30\end{array}$ \\
\hline End & $\begin{array}{l}5.0 \mathrm{~kg} \text { hay } \mathrm{A}^{*} \\
7.5 \mathrm{~kg} \text { hay } \mathrm{A} \\
5.0 \mathrm{~kg} \text { hay } \mathrm{B}\end{array}$ & $\begin{array}{l}1319 \\
1225 \\
1351\end{array}$ & $\begin{array}{l}71 \\
72 \\
78\end{array}$ & $\begin{array}{l}34 \\
43 \\
40\end{array}$ & $\begin{array}{l}2 \cdot 1 \\
1 \cdot 7 \\
2 \cdot 0\end{array}$ & $\begin{array}{l}\text { I } 59 \\
142 \\
\text { I } 53\end{array}$ & $\begin{array}{l}25 \\
2 I \\
24\end{array}$ \\
\hline
\end{tabular}

\begin{tabular}{|c|c|c|c|c|c|c|}
\hline Beginning & I 571 & 75 & 19 & 4.0 & 103 & $\mathbf{I} 3$ \\
\hline One-third & I395 & 79 & 29 & $2 \cdot 8$ & I 75 & 27 \\
\hline Two-thirds & I 340 & 77 & 35 & $2 \cdot 3$ & 177 & 28 \\
\hline End & I 298 & 74 & 39 & $1 \cdot 9$ & I 5 I & 23 \\
\hline SE of difference between two & $\pm 4 I \cdot 9$ & $\pm 1 \cdot 3$ & $\pm I \cdot 8$ & \pm 0.21 & $\pm 7 \cdot 8$ & \pm 0.9 \\
\hline
\end{tabular}
means† 
of collection of boluses throughout a meal the mean particle size of herbage was always greater than that of hay (Table 8). Contrary to the result observed when the cows received $5 \mathrm{~kg}$ hay $\mathrm{A}$ in Expt $\mathrm{I}$ there was no consistent trend towards a smaller mean particle size of herbage as the meal progressed (Table 8 ).

Table 7. Expt ז $b$. Mean particle size of swallowed food, time spent eating, numbers of jaw movements and of food boluses and weight of a bolus, determined on 3 days in two cows each receiving two diets

\begin{tabular}{|c|c|c|c|c|c|c|c|c|}
\hline \multirow[b]{2}{*}{$\begin{array}{l}\text { Daily } \\
\text { diet }\end{array}$} & \multirow[b]{2}{*}{ Cow } & \multirow{2}{*}{$\begin{array}{c}\text { Median } \\
\text { particle } \\
\text { size of } \\
\text { swallowed } \\
\text { hay } \\
(\mu \mathrm{m})\end{array}$} & \multirow{2}{*}{$\begin{array}{l}\text { Time } \\
\text { spent } \\
\text { eating } \\
\text { (min) }\end{array}$} & \multicolumn{2}{|c|}{$\begin{array}{l}\text { No. of jaw } \\
\text { movements }\end{array}$} & \multirow{2}{*}{$\begin{array}{l}\text { No. of } \\
\text { boluses/ } \\
\text { min }\end{array}$} & \multicolumn{2}{|c|}{$\begin{array}{l}\text { Weight of } \\
\text { bolus (g) }\end{array}$} \\
\hline & & & & $\begin{array}{l}\text { Per } \\
\text { min }\end{array}$ & $\begin{array}{c}\text { Per } \\
\text { bolus }\end{array}$ & & Wet & Dry \\
\hline $5 \mathrm{~kg}$ hay $\mathrm{A}$ & $\begin{array}{l}\text { Sylph } \\
\text { Polly } \\
\text { Mean }\end{array}$ & $\begin{array}{l}1348 \\
1279 \\
1314\end{array}$ & $\begin{array}{l}62 \\
64 \\
63\end{array}$ & $\begin{array}{l}72 \\
73 \\
72\end{array}$ & $\begin{array}{l}26 \\
27 \\
26\end{array}$ & $\begin{array}{l}2 \cdot 9 \\
2 \cdot 8 \\
2 \cdot 9\end{array}$ & $\begin{array}{l}114 \\
127 \\
121\end{array}$ & $\begin{array}{l}20 \\
21 \\
20\end{array}$ \\
\hline $20.6 \mathrm{~kg}$ herbage & $\begin{array}{l}\text { Sylph } \\
\text { Polly } \\
\text { Mean }\end{array}$ & $\begin{array}{l}1972 \\
2169 \\
2070\end{array}$ & $\begin{array}{l}65 \\
53 \\
59\end{array}$ & $\begin{array}{l}85 \\
77 \\
81\end{array}$ & $\begin{array}{l}2 \mathrm{I} \\
20 \\
2 \mathrm{I}\end{array}$ & $\begin{array}{l}4 \cdot 1 \\
3 \cdot 8 \\
3 \cdot 9\end{array}$ & $\begin{array}{l}179 \\
181 \\
180\end{array}$ & $\begin{array}{l}2 \mathrm{I} \\
2 \mathrm{I} \\
2 \mathrm{I}\end{array}$ \\
\hline $\begin{array}{l}\text { SE of difference } \\
\text { two diet means }\end{array}$ & $\begin{array}{l}\text { etween } \\
9 \mathrm{df})^{*}\end{array}$ & \pm 137.8 & $\pm 3 \cdot 3$ & $\pm 2 \cdot 3$ & \pm 0.5 & \pm 0.08 & $\pm 7 \cdot 5$ & $\pm I \cdot 2$ \\
\hline
\end{tabular}

* Derived from a pooled error of 'cows $x$ diets', $\mathrm{I}$ df, and 'days within cows and diets, $8 \mathrm{df}$.

Table 8. Expt $\mathrm{r} b$. Mean particle size of swallowed food, numbers of jaw movements and of food boluses and weight of a bolus, determined on 3 days at intervals during a meal in two cows each receiving two diets

\begin{tabular}{|c|c|c|c|c|c|c|c|}
\hline \multirow{2}{*}{$\begin{array}{l}\text { Time } \\
\text { during } \\
\text { meal }\end{array}$} & \multirow[b]{2}{*}{$\begin{array}{l}\text { Daily } \\
\text { diet }\end{array}$} & \multirow{2}{*}{$\begin{array}{l}\text { Median } \\
\text { particle } \\
\text { size of } \\
\text { swallowed } \\
\text { food } \\
(\mu \mathrm{m})\end{array}$} & \multicolumn{2}{|c|}{$\begin{array}{l}\begin{array}{l}\text { No. of jaw } \\
\text { movements }\end{array} \\
\end{array}$} & \multirow{2}{*}{$\begin{array}{l}\text { No. of } \\
\text { boluses/ } \\
\text { min }\end{array}$} & \multicolumn{2}{|c|}{$\begin{array}{l}\text { Weight of } \\
\text { bolus }(\mathrm{g})\end{array}$} \\
\hline & & & $\begin{array}{l}\text { Per } \\
\text { min }\end{array}$ & $\begin{array}{l}\text { Per } \\
\text { bolus }\end{array}$ & & Wet & Dry \\
\hline Beginning & $\begin{array}{l}5.0 \mathrm{~kg} \text { hay } A^{*} \\
20.6 \mathrm{~kg} \text { herbage }\end{array}$ & $\begin{array}{l}1418 \\
2030\end{array}$ & $\begin{array}{l}68 \\
8 I\end{array}$ & $\begin{array}{l}\text { I7 } \\
\text { I7 }\end{array}$ & $\begin{array}{l}3 \cdot 9 \\
4 \cdot 7\end{array}$ & $\begin{array}{r}72 \\
100\end{array}$ & $\begin{array}{l}\text { I I } \\
\text { IO }\end{array}$ \\
\hline One-third & $\begin{array}{l}5.0 \mathrm{~kg} \text { hay } A^{*} \\
20.6 \mathrm{~kg} \text { herbage }\end{array}$ & $\begin{array}{l}1328 \\
1875\end{array}$ & $\begin{array}{l}75 \\
83\end{array}$ & $\begin{array}{l}28 \\
22\end{array}$ & $\begin{array}{l}2 \cdot 7 \\
3 \cdot 9\end{array}$ & $\begin{array}{l}146 \\
189\end{array}$ & $\begin{array}{l}26 \\
22\end{array}$ \\
\hline Two-thirds & $\begin{array}{l}5.0 \mathrm{~kg} \text { hay } \mathrm{A}^{*} \\
20.6 \mathrm{~kg} \text { herbage }\end{array}$ & $\begin{array}{l}1302 \\
2013\end{array}$ & $\begin{array}{l}69 \\
81\end{array}$ & $\begin{array}{l}27 \\
22\end{array}$ & $\begin{array}{l}2 \cdot 5 \\
3 \cdot 6\end{array}$ & $\begin{array}{l}145 \\
212\end{array}$ & $\begin{array}{l}25 \\
25\end{array}$ \\
\hline End & $\begin{array}{l}5.0 \mathrm{~kg} \text { hay A } \\
20.6 \mathrm{~kg} \text { herbage }\end{array}$ & $\begin{array}{l}1208 \\
2364\end{array}$ & $\begin{array}{l}77 \\
78\end{array}$ & $\begin{array}{l}33 \\
22\end{array}$ & $\begin{array}{l}2 \cdot 3 \\
3 \cdot 5\end{array}$ & $\begin{array}{l}118 \\
219\end{array}$ & $\begin{array}{l}20 \\
27\end{array}$ \\
\hline \multicolumn{8}{|c|}{ Mean values with standard errors for both diets } \\
\hline $\begin{array}{l}\text { Beginning } \\
\text { One-third } \\
\text { Two-thirds } \\
\text { End }\end{array}$ & & $\begin{array}{l}1724 \\
1601 \\
1658 \\
1786\end{array}$ & $\begin{array}{l}75 \\
79 \\
75 \\
77\end{array}$ & $\begin{array}{l}17 \\
25 \\
25 \\
27\end{array}$ & $\begin{array}{l}4 \cdot 3 \\
3 \cdot 3 \\
3 \cdot 0 \\
2 \cdot 9\end{array}$ & $\begin{array}{r}86 \\
168 \\
179 \\
169\end{array}$ & $\begin{array}{l}\text { I I } \\
24 \\
25 \\
23\end{array}$ \\
\hline \multicolumn{2}{|c|}{$\begin{array}{l}\text { SE of difference between two } \\
\text { means } \nmid\end{array}$} & $\pm 92 \cdot 9$ & $\pm x \cdot 7$ & $\begin{array}{l} \pm \mathbf{I} \cdot \mathbf{I} \\
\text { arison. }\end{array}$ & \pm 0.18 & $\pm 7 \cdot 5$ & $\pm I \cdot 3$ \\
\hline
\end{tabular}




\section{Time spent eating}

Expt $\mathrm{1}$. There was considerable variation between individual cows in the time taken to eat $5 \mathrm{~kg}$ hay A (Table 3 ): Dorrit 36 took $94 \mathrm{~min}$, Begum $78 \mathrm{~min}$ and the other four cows (Polly 2, Elite, Sylph and Polly) ate more rapidly and spent on average $62 \mathrm{~min}$ eating.

Expt I $a$. The mean times spent eating ( $77 \mathrm{~min}$ or $15.4 \mathrm{~min} / \mathrm{kg}$ hay) by the three cows (Dorrit 36 , Begum and Polly 2) were similar when given $5 \mathrm{~kg}$ hay A or $5 \mathrm{~kg}$ hay $\mathrm{B}$. When given $7.5 \mathrm{~kg}$ hay $\mathrm{A}$ the mean time spent eating increased to $137 \mathrm{~min}$ or I $8.3 \mathrm{~min} / \mathrm{kg}$ hay (Table 5 ). The increase in the time spent eating per $\mathrm{kg}$ hay when the amount offered was increased by $50 \%$ is in agreement with that found by Freer et al. (1962). Consistent differences between the three cows in the rate of eating were observed; on each of the three diets Dorrit $3^{6}$ spent the longest time eating and Polly 2 the shortest.

Expt $\mathrm{I} b$. The mean time spent eating $20.6 \mathrm{~kg}$ herbage was $59 \mathrm{~min}$, a slightly shorter time than with $5 \mathrm{~kg}$ hay A, which contained about the same amount of dry matter (Table 7). The difference of 4 min between the times taken to eat the diets was not significant. Polly ate the herbage more quickly than Sylph and at a faster rate than she ate hay.

\section{Number of jaw movements}

Expt I. In Table 3 the numbers of jaw movements are expressed both per min and per bolus of swallowed food. The mean number of jaw movements per min was 74 , which was of the same order as those reported by Kick et al. (1937), Duckworth \& Shirlaw (1958) and Balch (1958). There was no evidence of any statistically significant differences between cows in the mean number of jaw movements per min, which varied only from 77 in Elite to 72 in Sylph. Rates of jaw movements did not vary markedly throughout a meal.

When the numbers of jaw movements were calculated per bolus, it was found that the number varied from $3^{1}$ per bolus in Dorrit $3^{6}$ to 23 per bolus in Begum (Table 3 ). In all the cows the mean number of jaw movements per bolus was significantly less at the beginning of a meal than at any other time $(P<0.00 \mathrm{I})$, and there was a tendency for the highest values to be found at the end of a meal (Table 4).

Expt I $a$. Increasing the daily amount of hay A from $5.0 \mathrm{~kg}$ to $7.5 \mathrm{~kg}$ was not associated with any statistically significant change in the mean number of jaw movements per min, but with the diet of $5 \mathrm{~kg}$ hay $\mathrm{B}$ all three cows tended to chew at a significantly higher $(P<0.00 \mathrm{I})$ rate and the mean value was 79 per min (Table 5$)$. With all three diets no pronounced change occurred in the frequency of jaw movements per min throughout a meal (Table 6), although there was a tendency to lower frequencies at the beginning and end of a meal. The mean numbers of jaw movements per bolus were higher with the diets of $7.5 \mathrm{~kg}$ hay A and $5 \mathrm{~kg}$ hay B than with $5 \mathrm{~kg}$ hay A (Table 5), and with each of the diets the number of jaw movements per bolus was lowest at the beginning of a meal and highest at the end (Table 6).

Expt $\mathrm{x} b$. The mean number of jaw movements per min was significantly higher $(P<0.01)$ with herbage $(8 \mathrm{r} / \mathrm{min})$ than with $5 \mathrm{~kg}$ hay A $(72 / \mathrm{min})$, and the increase in 
the number of movements with the diet of herbage occurred in both cows (Table 7 ). With the diet of $20.6 \mathrm{~kg}$ herbage the rate of jaw movements remained about the same throughout a meal; with a diet of $5 \mathrm{~kg}$ hay A there was a tendency for the number of jaw movements per min to be lower at the beginning of eating than at any other time (Table 8). None of the differences was statistically significant. The mean number of jaw movements per bolus of food was significantly less $(P<0.00 \mathrm{I})$ with the diet of herbage ( $2 \mathrm{r} /$ bolus) than with $5 \mathrm{~kg}$ hay (26/bolus) (Table 7 ). With diets of herbage and hay the number of jaw movements per bolus was lower at the beginning of a meal than at any other time (Table 8).

\section{Number of boluses}

Expt I. The mean number of boluses of food swallowed per min ranged widely between cows, from $3 \cdot 4 / \mathrm{min}$ in Begum to $2 \cdot 6 / \mathrm{min}$ in Dorrit 36 , but the rates of swallowing boluses by the other four cows did not differ significantly (Table 3 ). In each of the six cows the rate of swallowing boluses was highest at the beginning of a meal with a mean vaue of about $4 / \mathrm{min}$ and fell during the meal to about $2 / \mathrm{min}$ at the end of eating ('Table 4).

Expt r $a$. The type of hay given to the cows had little effect on the mean rate of swallowing boluses of food, but there was a tendency for the rate of swallowing to be lowest with $7 \cdot 5 \mathrm{~kg}$ hay A ('Table 5). With all three diets the number of boluses swallowed per min was highest at the beginning of a meal and lowest at the end (Table 6).

Expt I $b$. The mean rate of swallowing boluses of herbage $(3 \cdot 9 / \mathrm{min})$ was significantly higher $(P<0.001)$ than that observed with $5 \mathrm{~kg}$ hay A $(2 \cdot 9 / \mathrm{min})$ (Table 7$)$. During a meal of herbage the number of boluses swallowed declined from $4.7 / \mathrm{min}$ at the start of a meal to $3.5 / \mathrm{min}$ at the end (Table 8). The mean rates of swallowing boluses of food in Expts $1, \mathrm{I} a$ and $\mathrm{I} b$ tended to be in agreement with those reported from this laboratory by Bailey (196I) for diets of hay and fresh grass with cows similar to those used in the study now presented.

\section{Weight of boluses}

Expt I. The wet and dry weights of a bolus varied between cows; the heaviest were found in Dorrit 36 with a mean weight of $173 \mathrm{~g}$ containing $27 \mathrm{~g}$ dry matter and the lightest in Sylph with mean weights of I I $4 \mathrm{~g}$ and $20 \mathrm{~g}$ dry matter (Table 3 ). The weight of a bolus varied with the time of collection during a meal; boluses caught at the beginning of a meal were considerably lighter in both wet and dry weight than those collected later in the meal, although there was also some tendency for the size of the boluses to decrease at the very end of eating (Table 4). The amounts of saliva in each bolus could not be measured accurately because the boluses were caught by hand and some loss of saliva or addition of moisture may have occurred in catching and removing them from the rumen. Balch (1958) and Bailey (196r) both found with diets of hay that there was a tendency for the amount of saliva added to each gramme of food to decline throughout a meal.

Expt I $a$. The mean wet and dry weights of boluses of swallowed hay were slightly lower when the cows were given $7.5 \mathrm{~kg}$ hay A (I44. and $2 \mathrm{I} \mathrm{g}$ respectively) than with 
$5 \mathrm{~kg}$ hay A or $5 \mathrm{~kg}$ hay B ( $155 \mathrm{~g}$ wet and $24 \mathrm{~g}$ dry) (Table 5 ). It was again observed with $7.5 \mathrm{~kg}$ hay $\mathrm{A}$ and $5 \mathrm{~kg}$ hay $\mathrm{B}$ that boluses collected at the beginning of a meal weighed less and contained less dry matter than at any other time, the largest boluses were those collected during the middle of a meal and slightly smaller boluses were found at the end (Table 6).

Expt $\mathrm{x} b$. When the cows received herbage, the mean weight of a bolus ( $180 \mathrm{~g}$ ) was heavier than with hay (I2I g), but the mean weights of dry matter per bolus were 20-21 $\mathrm{g}$ with both diets (Table 7). As with a diet of hay, the smallest boluses were those collected at the beginning of a meal of herbage, but with herbage there was no decline in the weight of a bolus at the end of a meal.

Throughout the study it was observed that the mean weight of a bolus and its weight of dry matter were considerably greater than those found by Bailey (x96r) in this laboratory using similar cows given diets of hay and fresh grass; the explanation of this difference is not known.

\section{DISCUSSION}

The empirical technique of sieving used here to measure the size of particles of food contained in boluses of swallowed food is slow and tedious and the development of a rapid technique of measurement would be worth while. Sieving is possibly not the best technique to use in measuring particles of swallowed hay, which are typically long and narrow in shape. Although Silver (1935) was apparently able to sieve material from untreated dried boluses, we found it necessary to remove as much saliva as possible from the food to prevent clumping of the particles during drying.

In Expt I significant differences were found between cows in the median size of particles of swallowed hay. The reasons for these differences are not known. Among the six cows in Expt I those that chewed most per kg hay tended to swallow hay particles of the largest median size, and a similar relationship was indicated among the very few cows used in Expts $\mathrm{I} a$ and $\mathrm{x} b$. The correlation coefficient between median particle size of swallowed hay and the number of jaw movements per $\mathrm{kg}$ hay in Expt I was $+0.96(P<0.01)$. The correlation does not imply that for a given cow a greater number of jaw movements per $\mathrm{kg}$ food produces larger particles of swallowed food. In fact the results of Expts I $a$ and I $b$ showed that for a given cow diets associated with high numbers of jaw movements per $\mathrm{kg}$ food were also associated with small median particle size of swallowed food. In Expt I one of the cows differed markedly from the other five: Dorrit 36 spent longer eating and reduced the particles of hay to a much lesser extent than the other cows. Although her jaw movements per min did not differ significantly from the mean, Dorrit $3^{6}$ required most jaw movements per bolus and swallowed heavier boluses than the other cows. The reasons for these differences are not known; Dorrit 36 possessed a full complement of teeth but was 12 years old, whereas the other cows were on average 6 years old. Silver (1935) found some indication that younger animals were more active in chewing, resulting in greater disintegration of the food. Also, some months after the experiment Dorrit 36 was found to have advanced tuberculosis although this cow had regularly passed the routine single intradermal test. 
During a meal of hay the particle size of swallowed food was largest at the beginning of a meal. This was associated with smaller numbers of jaw movements per bolus, lighter boluses, and more rapid swallowing of boluses than at any other time during eating (Table 4). Similarly, the larger particle size of swallowed herbage than of swallowed hay was associated with a much more rapid rate of swallowing and slightly more jaw movements per min, but not per bolus. Bailey (196I) found that the rate of swallowing food was related to the moisture in the food and the rate of secretion of saliva, and he observed higher rates of swallowing with fresh grass and silage than with dried grass and hay. A plentiful supply of saliva at the beginning of eating may enable hay to be swallowed then more rapidly than at any other time, and it has been observed that the sight or smell of food or the noise of food being handled or eaten caused increases in the secretion of parotid saliva in the resting sheep (Denton, 1957; Somers, 1957).

The finding that the frequency of jaw movements did not alter appreciably throughout a meal agrees with that of Balch (1958), but not with the observation of Duckworth \& Shirlaw (1958). Also, it has been observed in grazing cows that a marked and progressive decline in jaw movements per min occurred during each period of grazing (Hancock, 1950); no explanation can be offered for these differences.

The authors are grateful to Mr V. W. Johnson and his colleagues for caring for the animals.

\section{REFERENCES}

Bailey, C. B. (196r). Br. F. Nutr. I5, 443.

Bailey, C. B. \& Balch, C. C. (196r). Br. F. Nutr. I5, 37 I.

Balch, C. C. (1958). Br. F. Nutr. 12, 330.

Balch, C. C. \& Campling, R. C. (1962). Nutr. Abstr. Rev. 32, 669.

Balch, C. C. \& Cowie, A. T. (I962). Cornell Vet. 52, 206.

Balch, C. C., Johnson, V. W. \& Machin, C. (1962). F. agric. Sci., Camb., 59, 355.

Bryant, A. M. (1964). Proc. N.Z. Soc. Anim. Prod. 24, 57.

Campling, R. C., Freer, M. \& Balch, C. C. (196r). Br. $\mathscr{J}$. Nutr. 15, 531 .

Denton, D. A. (1957). Nature, Lond., r79, 341 .

Duckworth, J. E. \& Shirlaw, D. W. (1958). Anim. Behav. 6, I47.

Dukes, H. H. (1955). The Physiology of Domestic Animals. Ithaca, N.Y.: Comstock Publishing Ass.

Freer, M., Campling, R. C. \& Balch, C. C. (1962). Br. F. Nutr. 16, 279.

Fuller, J. M. (1928). Tech. Bull. New Hamps. agric. Exp. Stn, no. 35.

Hancock, J. (1950). N.Z. Fl Sci. Technol. A, 32, 22.

Kick, C. H. \& Gerlaugh, P. (1935). Proc. Am. Soc. Anim. Prod. p. 93.

Kick, C. H., Gerlaugh, P., Schalk, A. F. \& Silver, E. A. (I937). Yl agric. Res. 55, 587.

Reid, C. S. W., Lyttleton, J. W. \& Mangan, J. L. (I962). N.Z. Yll agric. Res. 5, 237.

Schalk, A. F. \& Amadon, R. S. (1928). Bull. N. Dak. agric. Exp. Stn, no. 216.

Silver, E. A. (1935). Agric. Engng, St Joseph, Mich. 16, 257.

Somers, M. (1957). Aust. vet. F. 33, 297.

Troelsen, J. E. \& Bigsby, F. W. (1964). \%. Anim. Sci. 23, I I39. 